\title{
KERION CELSI YANG DISEBABKAN OLEH TRICOPHYTON VERRUCOSUM PADA PASIEN IMUNOKOMPROMAIS
}

\author{
Alfonsus Rendy Laksditalia Nugroho, Santosa Basuki \\ Departemen/SMF Dermatologi dan Venereologi \\ FK Universitas Brawijaya/RSUD dr.Saiful Anwar, Malang
}

\begin{abstract}
ABSTRAK
Kerion celsi merupakan manifestasi inflamasi pada infeksi dermatofita zoofilik diskalp. Salah satu penyebabnya adalah Trichophyton verrucosum. Imunitas seluler pada pasien imunokompromais terganggu sehingga rentan terinfeksi dermatofita.

Pria, 73 tahun mengeluh benjolan bernanah di kepala yang nyeri dan gatal sejak 3 bulan sebelum konsultasi. Pada pemeriksaan dermatologis parietal skalp didapatkan alopesia berbatas tegas dengan boggy eritematosa $5 \mathrm{~cm}$ dan pustul folikular. Pemeriksaan dengan lampu Wood tidak menunjukkan fluoresensi. Pemeriksaan mikroskopik dengan $\mathrm{KOH} 20 \%$ didapatkan hifa dan artrokonidia ektotriks. Numerical rating score (NRS) nyeri 8, dan gatal 4. Identifikasi kultur kerokan kulit kepala dan rambut menunjukkan Trichophyton verrucosum. Pasien didiagnosis kerion celsi, diterapi dengan griseofulvin microsized $20 \mathrm{mg} / \mathrm{kg}$ berat badan/hari selama 8 minggu, dan prednison $0,5 \mathrm{mg} / \mathrm{kg}$ berat badan/hari selama 10 hari yang kemudian diturunkan perlahan. Ditambahkan krim terbinafine HCL $1 \%$ didahului kompres basah dua kali sehari. Setelah 8 minggu, perbaikan NRS mencapai nol, tanpa efek samping.

Kerion celsi seringkali terjadi pada anak, jarang pada dewasa. Pada kasus ini terjadi pada pasien neoplasma berusia lanjut dalam kemoterapi. Usia lanjut, kanker paru, kemoterapi geftinib, diabetes mellitus dan kontak langsung dengan hewan peliharaan merupakan faktor risiko kondisi imunokompromais dan inokulasi patogen sehingga mempermudah dermatofita menginvasi rambut.
\end{abstract}

Kata kunci: kerion celsi, Tricophyton verrucosum, imunokompromais, griseofulvin

\section{KERION CELSI CAUSED BY TRICOPHYTON VERRUCOSUM ON IMMUNOCOMPROMISED PATIENT}

\section{Korespondensi:}

Jl. Jaksa Agung Suprapto

Telp/Fax 0341-340991

Email:kulit_fkub@yahoo.com ;

rendylaksditalia@gmail.com

\begin{abstract}
Kerion celsi is manifestation of inflammation in zoophilic dermatophytes scalp infection. One of its causative agents is Tricophyton verrucosum. Disturbed cellular immunity on immunocompromised patient bring susceptibility for dermatophyte infection.

Male, 73 years old, complained painful and itch bump since 3 months. Dermatological examination of parietal scalp showed well defined alopecia with $5 \mathrm{~cm}$ boggy erythematous and with follicular pustule. Wood lamp showed no fluorescence. Microscopic examination with potassium hydroxide 20\% showed hyphae and ectothrix arthroconidia. Numerical rating score (NRS) of initial pain was 8 and itch was 4 . Identification of skin scraping and hair cultures showed Tricophyton verrucosum. Patient was diagnosed as kerion celsi and treated with microsized griseofulvin $20 \mathrm{mg} / \mathrm{kg}$ body weight/day and oral prednisone $0.5 \mathrm{mg} / \mathrm{kg}$ body weight/day which being tapered off in 10 days. Terbinafine cream $1 \%$ twice, prior twice daily wet gauze compress also being given. After 8 weeks, NRS reach zero without any side effects.

Kerion celsi often happen on children. Within this case, it occurred in a geriatric patient with neoplasma during chemotherapy. Old age, lung cancer, geftinib chemotherapy, diabetes mellitus and direct contact with infected domestic animal were risk factors for immunocompromised state and pathogen inoculation that may facilitate dermatophyte hair invasion.
\end{abstract}

Keywords: kerion celsi, Tricophyton verrucosum, immunocompromised, griseofulvin 


\section{PENDAHULUAN}

Kerion celsi, yang dalam bahasa Yunani berarti sarang lebah, merupakan reaksi inflamasi kulit pejamu (manusia) karena dermatofita. ${ }^{1}$ Infeksi dermatofita pada kulit pejamu akan mencetuskan spektrum klinis reaksi inflamasi. Pada infeksi dermatofita jenis tinea kapitis, spektrum klinis yang dihasilkan dapat berupa lesi kulit yang berskuama non-inflamasi hingga inflamasi berat dengan karakteristik kerion yang dalam dan dapat berulserasi.

Kerion celsi menunjukkan keunikan tersendiri karena gambaran khas berupa massa inflamasi berbentuk boggy, berbatas tegas, dengan supurasi yang berasal dari orifisium folikular. Secara klinis,bentuk lesi semacam ini berbeda dari infeksi dermatofita zoofilik yang seringkali disebabkan oleh Trichophyton mentagrophytes var mentagrophytes atau Trichophyton verrucosum. ${ }^{2}$ Kondisi klinis yang tidak umum tersebut seringkali menyebabkan diagnosis tertunda karena sangat bergantung pada pengenalan morfologi lesi kulitnya. ${ }^{1}$

Selain kerion celsi, gambaran klinis tinea kapitis lain adalah tipe non-inflamasi yaitu gray patch, pola 'black dot', serta yang bermanifestasi sebagai pustul di daerah skalp., Tipe mana yang akan muncul tergantung pada interaksi antara pejamu dan dermatofita. ${ }^{3,5}$ Satu penelitian di Rumah Sakit dr. Cipto Mangunkusumo (RSCM), Jakarta melaporkan frekuensi bentuk klinis tinea kapitis dan kerion celsi merupakan bentuk yang paling sering ditemukan $(65,21 \%)$, diikuti gray patch $(26,09 \%)$ dan tipe black dot $(8,70 \%){ }^{6}$ Distribusi penyakit ini tersebar di seluruh dunia. ${ }^{7}$

Kerion celsi sebenarnya dapat mengalami involusi spontan dengan derajat jaringan parut yang bervariasi. Namun, terapi spesifik dengan griseofulvin akan memper- pendek perjalanan penyakit sehingga mencegah pembentukan jaringan parut yang lebih luas. ${ }^{1}$ Kortikosteroid oral, yaitu prednison diberikan sebagai pengobatan tambahan pada kerion celsi dengan tujuan untuk mengurangi nyeri, bengkak, dan peradangan. ${ }^{8-11}$ Liu dkk. menyajikan sebuah laporan kasus yang mengemukakan keberhasilan terapi kerion celsi pada pasien imunokompromais dengan kombinasi antifungi, evakuasi pus dan prednison oral jangka pendek yang diturunkan perlahan dosisnya hingga dihentikan pada hari ke-10. ${ }^{11}$

Imunokompromais adalah kondisi defisiensi imun oleh penyebab apapun, sehingga kemampuan sistem imun untuk melawan infeksi berkurang atau sepenuhnya hilang. Dalam keadaan tersebut imunitas seluler pasien terganggu sehingga rentan terhadap infeksi, termasuk dermatofita. ${ }^{12}$ Tinea kapitis secara primer umum ditemukan pada anak dan sangat jarang pada orang dewasa. ${ }^{5,13}$ Pasien dewasa dengan penyakit kanker berada dalam status imunokompromais yang berat berisiko terhadap infeksi dermatofita. ${ }^{14}$

Berikut akan dilaporkan satu kasus kerion celsi yang disebabkan oleh Trichophytonverrucosum pada pria 73 tahun dalam kondisi imunokompromais dengan penilaian awal NRS nyeri sebesar 8 dan NRS gatal sebesar 4 .

\section{KASUS}

Laki-laki, berusia 73 tahun, datang ke Poliklinik Rawat Jalan Kulit dan Kelamin Rumah Sakit Saiful Anwar Malang dengan keluhan sejak 3 bulan sebelumnya timbul satu benjolan bernanah di kulit kepala. Awalnya benjolan sebesar lingkar jari namun semakin luas, menebal dan berwarna kemerahan (Gambar 1). 


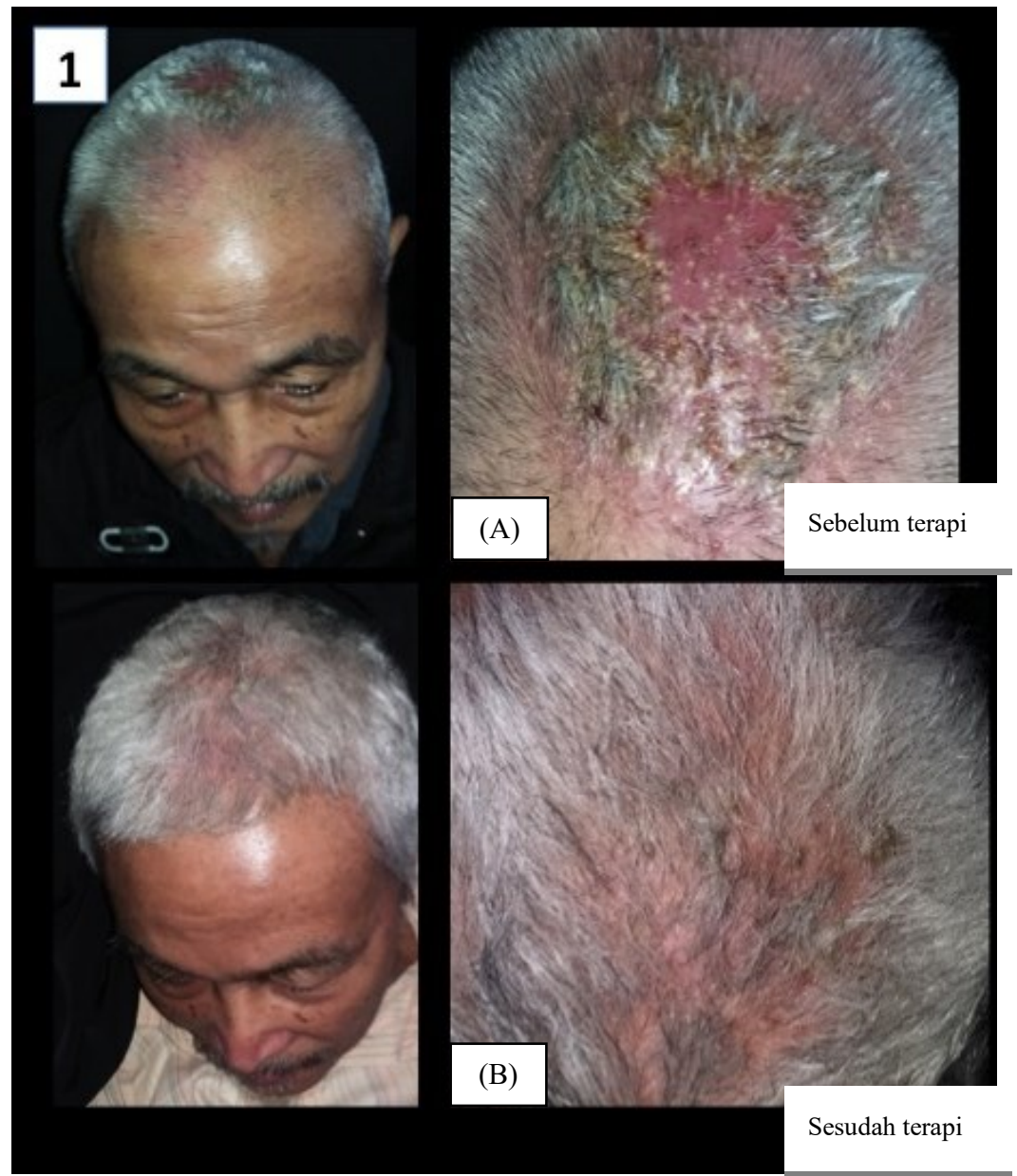

Gambar 1. Manifestasi klinis lesi kerion celsi sebelum terapi (A) dan setelah terapi (B) griseofulvin microsized $20 \mathrm{mg} / \mathrm{kg}$ berat badan/hari selama $8 \mathrm{minggu}$, serta prednison $0,5 \mathrm{mg} / \mathrm{kg}$ berat badan/hari selama 10 hari yang diturunkan bertahap.

Benjolan terasa nyeri dan semakin nyeri bila disentuh. Benjolan juga dirasa gatal meskipun rasa nyeri terasa lebih dominan dibanding rasa gatal. Rasa gatal bertambah bila pasien berkeringat atau bila udara terasa panas. Intensitas gatal lebih dirasakan di pagi hari saat pasien beraktivitas. Setiap kali terasa gatal pasien akan menggaruk dan setiap kali digaruk, terasa serpihan kulit kepala yang terlepas diikuti rambut yang rontok. Rambut di benjolan tersebut semakin menipis dan meninggalkan area botak yang melingkar. Satu minggu kemudian, muncul lenting-lenting kecil di sekitar benjolan merah dan bila digaruk lenting tersebut pecah, bernanah, dan terasa sedikit perih. Terdapat pula kerak di area tersebut. Pasien sempat memeriksakan diri ke dokter dan diberi tablet obat antibiotik selama dua minggu dan salep antibiotik fusidat namun belum didapatkan perbaikan yang berarti.

Sejak 13 bulan lalu pasien didiagnosis menderita kanker paru oleh Departemen Paru RSUD dr. Saiful
Anwar dan mendapat obat kemoterapi Iressa ${ }^{\circledR}$ (gefitinib) oral yang dikonsumsi setiap hari pukul 20.00. Saat ini sudah mencapai bulan ke-13 kemoterapi. Kulit pasien cenderung kering dan gatal sejak minum obat kemoterapi, namun membaik bila memakai pelembab. Pasien juga memiliki riwayat diabetes mellitus sejak enam tahun yang lalu, dan sejak beberapa bulan belakangan diterapi dengan tablet akarbose. Pasien didiagnosis hipertensi sejak lima tahun lalu, dan dua tahun lalu pernah mengalami serangan jantung dan dipasang ring. Riwayat terluka karena tertusuk benda tajam ataupun batang tanaman di kepala disangkal. Pasien tidak pernah mengalami keluhan demam. Selain keluhan kulit di kepala, ia tidak mengalami kelainan kulit di area tubuh lainnya. Kondisi kulit telapak tangan dan kaki pasien juga tidak pernah muncul lenting-lenting. Pasien selalu menjaga kebersihannya dengan baik, mandi dua kali sehari dan selalu mengganti pakaiannya. Pasien memelihara seekor kucing dalam rumah. Kucing tersebut mengalami kerontokan 
bulu di kepalanya. Tidak ada anggota keluarga lain yang sakit serupa dengan pasien.

Pemeriksaan dermatologis di daerah regio parietal skalp didapatkan plak, bulat berwarna dull-red dengan batas tegas, berdiameter $5 \mathrm{~cm}$, membasah disertai pus yang merembes dari pustul folikular, krusta kekuningan, skuama putih, dengan area alopesia berbatas tegas. Pemeriksaan lampu Wood tidak menunjukkan fluoresensi.

Dari pemeriksaan fisik didapatkan, tanda vital dalam batas normal, tensi $120 / 80 \mathrm{mmHg}$, nadi $90 \mathrm{x} / \mathrm{menit}$, frekuensi napas $20 \mathrm{x} /$ menit, dan suhu $36^{\circ} \mathrm{C}$, berat badan $55 \mathrm{~kg}$, tidak didapatkan pembesaran kelenjar getah bening regio koli, retroaurikular, aksila, dan inguinal.

Pemeriksaan mikroskopis dengan larutan $\mathrm{KOH} \mathrm{10 \%}$ dari kerokan kulit skalp tidak ditemukan gambaran hifa. Pada periksaan mikroskopis terhadap sediaan rambut yang direndam selama 24 jam terlebih dahulu dengan larutan $\mathrm{KOH} 20 \%$, didapatkan gambaran hifa panjang bersepta dan artrokonidia membentuk selubung di permukaan luar batang rambut.

Kultur jamur dari spesimen kerokan kulit dan rambut pasien, menunjukkan pertumbuhan Trichophyton verrucosum. Pada pasien ini terdapat komorbiditas multipel, sehingga interaksi obat terhadap obat-obatan yang dikonsumsi pasien patut dipertimbangkan untuk memutuskan pemberian terapi yang tepat. Pasien saat ini menggunakan Iressa ${ }^{\circledR}$ (geftinib), amlodipin, candesartan, akarbose, salbutamol, CTM, kodein, dan ondansetron. Itrakonazol dan flukonazol berinteraksi dengan obat Iressa $^{\circledR} \quad$ (geftinib) sedangkan griseofulvin tidak berinteraksi dengan obat-obat yang digunakan tersebut.

Pasien didiagnosis sebagai kerion celsi dan diterapi dengan microsized griseofulvin $1000 \mathrm{mg} 1 \mathrm{x} 1$ hari $(20$ $\mathrm{mg} / \mathrm{kgbb} /$ hari). Sebelum terapi, dilakukan pemeriksaan laboratorium. Didapatkan SGOT sebesar $10 \mathrm{U} / \mathrm{L}$ (nilai normal 0-40 U/L), SGPT 9 U/L (nilai normal 0-41 U/L), dan gula darah sewaktu sebesar $144 \mathrm{mg} / \mathrm{dL}$ (nilai normal kurang dari $200 \mathrm{mg} / \mathrm{dL}$ ). Direncanakan pula evaluasi pemeriksaan tes fungsi hati dan gula darah acak ulang setelah minggu kedua terapi. Pada minggu pertama terapi untuk menekan respons peradangan dan rasa nyeri pasien diberi prednison dosis $25 \mathrm{mg}(0,5 \mathrm{mg} / \mathrm{kg} / \mathrm{BB})$ hingga hari ke-5 yang kemudian diturunkan perlahan hingga hari ke10. Sebagai terapi adjuvan, dilakukan kompres dengan larutan $\mathrm{NaCl} 0,9 \%$ dua kali sehari selama 10 menit, kemudian diberikan krim terbinafin $\mathrm{HCl} 1 \%$ yang dioleskan dua kali sehari. Pasien dan istri pasien diedukasi tentang penyakit ini meliputi etiologi, faktor predisposisi, rencana pengobatan dan prognosis dari penyakit ini. Pasien juga diminta untuk tidak memakai berbagai barang yang berkontak dengan kepala pasien misalnya bantal, handuk, topi dll secara bersama-sama dengan anggota keluarga lain, untuk mencegah transmisi patogen. Pasien juga disarankan untuk mengobati sakit kulit dari kucing peliharaannya ke dokter hewan.
Follow up pada minggu pertama terapi didapatkan eritema dan rasa nyeri berkurang. Hasil NRS nyeri menurun dari 8 menjadi 5 dan NRS gatal masih tetap pada angka 4. Follow up pada minggu ketiga terapi rasa gatal dan nyeri makin berkurang. Keluhan subyektif pasien, eritema dan pustule berkurang, meskipun belum sepenuhnya tercapai kesembuhan klinis. Pemeriksaan evaluasi mikroskopik ulang dengan $\mathrm{KOH} 20 \%$ pada spesimen rambut di minggu ketiga terapi tidak mendapatkan hifa dan artrokonidia ektotriks . Hasil NRS nyeri menurun dari 5 menjadi 0 dan NRS gatal menurun dari 4 menjadi 3.

Terapi dilanjutkan hingga minggu kedelapan. Pada evaluasi terapi minggu kedelapan pasien tidak lagi mengeluh nyeri dan gatal. Hasil NRS nyeri 0 dan NRS gatal menurun dari 3 menjadi 0. Lesi kerion telah hilang sepenuhnya, menjadi area hiperpigmentasi yang mulai ditumbuhi rambut kembali dengan jaringan parut yang minimal (Gambar 1). Pemeriksaan evaluasi mikroskopik ulang dengan $\mathrm{KOH} \mathrm{20 \%} \mathrm{pada} \mathrm{spesimen} \mathrm{rambut} \mathrm{di} \mathrm{minggu}$ kedelapan terapi tidak mendapatkan hifa dan artrokonidia ektotriks. Hasil pemantauan tes fungsi hati dan gula darah sewaktu sesudah antijamur terapi oral dan kortikosteroid hingga minggu ke- 8 menunjukkan bahwa keduanya tetap dalam hasil kisaran nilai normal yaitu SGOT sebesar 12 U/L (nilai normal 0-40 U/L) dan SGPT $15 \mathrm{U} / \mathrm{L}$ (nilai normal 0-41 U/L) dan gula darah sewaktu sebesar 146 $\mathrm{mg} / \mathrm{dL}$ (nilai normal kurang dari $200 \mathrm{mg} / \mathrm{dL}$ ). Tidak ditemukan efek samping serius. Hal tersebut menunjukkan pemilihan obat griseofulvin dan terbinafin topikal tidak memengaruhi pengobatan kanker paru pasien.

\section{PEMBAHASAN}

Kerion celsi merupakan manifestasi infeksi dermatofita, terutama yang berasal dari binatang dan tanah. ${ }^{1}$ Berdasarkan ekologinya dermatofita terbagi atas golongan antropofilik, geofilik dan zoofilik. Spesies dermatofita geofilik bertahan hidup di lingkungan dengan materi keratin, antropofilik hanya menginfeksi manusia dan dermatofita zoofilik hanya menginfeksi hewan namun seringkali pula menginfeksi manusia. Artrokonidia (artrospora) yang muncul di lingkungan atau skuama kulit yang terkelupas adalah materi yang berperan dalam proses inokulasi.

Bentuk morfologis dermatofita tersebut dapat bertahan hidup hingga beberapa bulan di luar tubuh pejamu. Setelah proses inokulasi, artrokonidia akan menempel pada keratinosit. Protease yang disekresi oleh dermatofita berperan dalam fase penetrasi. Protease yang disekresi tersebut diidentifikasi sebagai faktor virulensi. Sekali menempel pada keratinosit manusia, dermatofita akan segera berpenetrasi ke stratum korneum, karena stratum korneum dan ostium folikel rambut menyediakan kebutuhan $\mathrm{pH}$ dan nutrisi untuk dermatofita. Proses 
tersebut dapat difasilitasi oleh perubahan kondisi lingkungan stratum korneum, contohnya kelembapan dan trauma. ${ }^{18}$

Saat dermatofita menginvasi kulit manusia, dermatofita akan dihadang oleh respons imun non spesifik dan respons imun seluler. Respons imun non spesifik bekerja menghadang dermatofita dengan terjadinya peningkatan turn over epidermis, peranan faktor serum yaitu unsaturated transferin, dan aktivasi sel polimorfonuklear di lokasi infeksi. Sementara itu, respons imun seluler dimulai setelah jamur yang hidup di stratum korneum bermultiplikasi dan melepaskan antigen. Berbagai penelitian menyimpulkan bahwa respons imun seluler berperan utama dalam perjalanan penyakit dan kesembuhan infeksi dermatofita. ${ }^{19}$

Komponen dermatofita yang bersifat antigenik adalah dinding miselium yang terdiri atas glikopeptida dan keratinase. Selain itu, dinding sel miselium mengandung manan yang terdiri atas glikoprotein dengan komposisi beragam pada tiap spesies dermatofita, yang semuanya bersifat juga sebagai antigen. Perbedaan struktur kimia manan yang beragam untuk spesies dermatofita berperan pada manifestasi inflamasi yang ditimbulkan, sehingga gambaran klinis dapat berbeda-beda dan perlu diidentifikasi spesies penyebabnya. ${ }^{19}$

Infeksi rambut oleh dermatofita mengikuti 3 pola utama berdasarkan tempat inokulasi artrospora, yaitu ektotriks, endotriks dan favus. Pada infeksi ektotriks, artrokonidia hanya terlihat di permukaan batang rambut, meskipun hifa juga didapat di dalam batang rambut; proses tersebut akan berlanjut dengan hancurnya kutikula. Kolonisasi dermatofita pada manusia oleh jamur zoofilik atau geofilik akan menghasilkan penyakit dengan tipe inflamasi tertentu. Infeksi ektotriks oleh Trichophyton sp. (Trichophyton mentagrophytes var mentagrophytes dan Trichophytonverrucosum) secara klinis nampak berbeda dengan yang lain karena reaksi inflamasi yang lebih hebat.

Pada infeksi oleh Trichophyton sp, kerion yang merupakan tipe inflamasi yang lebih berat, lebih sering terjadi dibandingkan dengan Microsporum sp. Pada inflamasi tipe kerion celsi timbul folikulitis supuratif dan infiltrasi subkutan. Gambaran 'boggy' disertai pus yang tampak membasah dari folikel. Pembengkakan tersebut nyeri dan rambut mudah lepas. Perlu digarisbawahi bahwa pus yang timbul bukan akibat infeksi sekunder dari invasi bakteri, namun dari dermatofita semata-mata, oleh karena itu tidak diperlukan terapi antibakteri (antibiotik). Seringkali, plak berwarna dull-red berbatas tegas yang dipenuhi pustul, dan disebut sebagai agminate folikulitis. Organisme patogen biasanya didapatkan dari kontak dengan hewan, yang merupakan sumber yang umum ditemukan. 2,4,11,20

Pada infeksi endotriks, artrokonidia dan hifa berada di dalam batang rambut dan korteks serta kutikula tetap utuh. Pola tinea kapitis ini memberi tampilan "black dot" yang terdiri atas rambut patah tepat di dekat orifisium folikel rambut dan meninggalkan conidia-filled stub area skalp. Semua dermatofita berpola endotriks adalah dermatofita antropofilik yang seringkali menyebabkan infeksi kronik disertai reaksi inflamasi minimal. Favus memiliki karakteristik hifa yang tersusun secara longitudinal dan didapatkan ruang berisi udara dalam batang rambut. Artrokonidia biasanya tidak terlihat di rambut yang terinfeksi. ${ }^{2,4,20}$

Pada kasus ini, didapatkan infeksi dermatofita ektotriks dengan gambaran artrokonidia di permukaan batang rambut pada pemeriksaan mikroskopis dengan KOH 20\%. Kemungkinan penyebab adalah Trichophyton verrucosum. Trichophyton verrucosum dengan manifestasi kerion celsi pertama kali dilaporkan di Korea oleh Kim dkk. pada tahun 1986. Seiring berjalannya waktu, telah dilaporkan 8 kasus kerion celsi akibat Trichophyton verrucosum, yang tujuh di antaranya akibat kontak dengan hewan ternak. Mengingat dermatofita ini merupakan dermatofita zoofilik, penting untuk menggali riwayat kontak dengan hewan domestik atau hewan peliharaan, begitu pula dengan penggunaan steroid atau obat imunosupresan. Pada kondisi klinis kerion celsi, elemen jamur seringkali tersebar dan sulit ditemukan di antara skuama atau krusta. Oleh karena itu, penting untuk memeriksa dan mengambil spesimen dari rambut yang terinfeksi. Karena $T$. verrucosum adalah jamur ektotriks yang meliputi permukaan eksternal batang rambut, maka akan menyebabkan infeksi yang lebih berat dibandingkan dengan jamur endotriks. ${ }^{20}$

Analisis kultur jamur pasien ini menghasilkan pertumbuhan spesies Trichophyton verrucosum. Didapatkan koloni makroskopis dari Trichopyton verrucosum pada agar Saboraud's dextrose seperti beludru (velvety) dengan peninggian di bagian tengah. Gambaran mikroskopik dari pengecatan lactophenol cotton blue menunjukkan banyak klamidospora yang berjajar seperti mutiara., ${ }^{1,21}$ Pada anamnesis didapatkan kontak dengan hewan yang diduga terinfeksi, meskipun pemeriksaan dermatologis tidak menunjukkan pendaran lampu Woods. Pemeriksaan dengan larutan $\mathrm{KOH}$ mendapatkan artrokonidia ektotriks. Ditambah lagi, manifestasi kerion celsi pada pasien ini yang lebih sering terjadi akibat dermatofita zoofilik, sesuai dengan temuan kultur yaitu Trichophyton verrucosum.

Faktor risiko tinea kapitis pada orang dewasa termasuk usia, dengan komorbiditas antara lain diabetes melitus, malnutrisi, penyakit genetik disertai defisiensi imun, anemia, kondisi imunosupresi, pengobatan kortikosteroid, perubahan hormon misalnya menopause, dan derajat pajanan yaitu tinea yang berlokasi di bagian tubuh manapun, kontak dengan anak kecil yang terinfeksi atau benda/materi yang dapat membawa patogen (fomites). ${ }^{13}$ Tinea kapitis secara primer pada umumnya ditemukan pada anak dan sangat jarang pada orang dewasa. ${ }^{5,13}$ Bergson dan Fernandes mengemukakan bahwa 
hanya sedikit laporan kasus tinea kapitis pada usia dewasa. Mereka menyimpulkan bahwa selama 49 tahun, dilaporkan hanya 90 kasus tinea kapitis yang menginfeksi orang dewasa, yaitu 79 orang wanita $(87,7 \%)$ dan 11 orang pria $(12,3 \%) .^{5}$

Prevalensi infeksi dermatofita telah meningkat secara bermakna pada dekade belakangan ini, secara khusus oleh karena peningkatan jumlah pasien dalam kondisi imunokompromais. Faktor risiko yang terdapat dalam populasi misalnya usia tua, peningkatan insidens dari penyakit tertentu, human immunodeficiency virus (HIV), diabetes melitus, keganasan atau terapi imunosupresif dinyatakan dalam beberapa kepustakaan sebanding dengan terjadinya peningkatan insidens infeksi jamur. Pasien dengan keganasan berada dalam kondisi imunokompromais yang berat sehingga berisiko terinfeksi dermatofita. ${ }^{14}$ Kondisi imunokompromais pada pasien ini adalah komorbiditas penyakit kanker paru adenobronchogenic dalam kemoterapi bulan ke-13 dengan geftinib, diabetes mellitus dan usia yang cukup lanjut.

Dalam satu studi kasus kontrol di Romania tahun 2015 mendapatkan frekuensi infeksi dermatofita sebesar $28,6 \%$ pada pasien yang menderita penyakit karsinoma paru. Didapatkan pula peningkatan yang bermakna pada kasus neoplastik lainnya yaitu leukemia, adenokarsinoma gaster, dan kanker payudara. ${ }^{14}$ Dalam laporan kasus ini, pasien menderita kanker adenobronkogenik paru .

Kesulitan utama dalam terapi pasien dengan penyakit neoplastik adalah memilih obat antijamur yang paling efektif. Terapi ini dapat menimbulkan efek samping yang tidak diinginkan yang berbahaya pada pasien dengan keganasan. Selain itu, pasien dengan komorbiditas ganda seperti pasien dalam laporan kasus ini, perlu dikaji lebih mendalam mengenai interaksi obat yang terjadi. Obat golongan azol dapat menjadi pilihan terapi untuk tinea kapitis. Namun dalam kondisi pasien yang mengkonsumsi obat-obatan karena penyakit yang ada sebelumnya, klinisi harus memperhatikan interaksi obat memilih terapi yang tepat penderita. Dalam kasus ini pasien tidak dapat diberikan obat golongan azol. Penggunaan golongan azol tidak dapat diberikan bersamaan dengan kemoterapi gefitinib, karena kerja obat golongan azole sebagai CYP3A4 inhibitors (anggota dari enzim sitokrom P450) yang akan menghambat metabolisme obat melalui hepar, sehingga menyebabkan kadarnya bertahan lebih lama di dalam darah dan berpotensi untuk menimbulkan toksisitas. Mengingat pemberian gefitinib adalah satu kali setiap hari, besar kemungkinan risiko toksik akan terjadi dengan penggunaan obat antijamur golongan azole. Pada pasien ini, digunakan obat antifungal golongan griseofulvin, meskipun golongan terbinafine masih memungkinkan. ${ }^{13,15,22}$

Kesembuhan klinis dicapai dengan perbaikan tanda klinis berupa eritema berkurang, skuama berlebihan, dan rambut tidak mudah tercabut. Kesembuhan mikologis dicapai dengan tidak ditemukannya artrokonidia (artrospora) pada pemeriksaan KOH 10-20\% dan kultur Saborauddextrose agar menunjukkan hasil negatif (tidak ada pertumbuhan dermatofita). Kesembuhan komplet, yaitu kesembuhan pada kedua aspek (baik klinis maupun mikologis) perlu dicapai sebelum pasien dinyatakan sembuh dan bebas terapi. ${ }^{22}$

Dari terapi yang telah diberikan selama 8 minggu pada pasien ini, pemantauan fungsi hepar dan gula darah acak hingga minggu kedelapan. Pemberian terapi saat ini tidak memperberat kondisi awal pasien dan tidak ditemukan efek samping serius. Hal tersebut sesuai dengan pemilihan obat griseofulvin dan terbinafin topikal yang tidak mempengaruhi penggunaan obat kanker paru. Pada follow up minggu pertama hingga minggu kedelapan, terhadap pengurangan rasa nyeri dan gatal pasca terapi hingga hilang sama sekali. Pada minggu ke 8 tampak lesi kerion telah hilang sepenuhnya, meninggalkan area hiperpigmentasi pada inflamasi yang mulai kembali ditumbuhi rambut. Pemeriksaan evaluasi mikroskopik ulang dengan $\mathrm{KOH} 20 \%$ pada spesimen rambut mulai di minggu ketiga terapi tidak menunjukan adanya hifa dan tidak didapatkan lagi artrokonidia ektotriks hingga minggu kedelapan.

\section{DAFTAR PUSTAKA}

1. O’Donnell B, Powell F, Hone R, O’Loughlin S. Kerionclinical spectrum in nine cases. Irish $\mathrm{J}$ Med Sci. 1990;1:159:14-8.

2. Rippon JW. Medical mycology the pathogenic fungi and the pathogenic actinomycetes. Edisi ke-2. Philadelphia: WB Saunders; 1982.h.154-80.

3. Kartadjukardi E, Triestianawati W. Tinea kapitis. MDVI. 2002;29:153-62.

4. Schieke M. Stefan, Garg Amit. Superficial fungal infection. Dalam: Wolff Klaus, Goldsmith Lowell A, Katz Stephen I, Gilchrest Barbara A, Paller Amy S, Leffel David J, penyunting. Fitzpatrick's Dermatology in General Medicine. Edisi ke 8. New York: McGraw-Hill; 2012.h.2277-97

5. Bergson CL, Fernandes NC. Tinea capitis: study of asymptomatic carriers and sick adolescents, adults and elderly who live with children with the disease. Revista do Instituto de Medicina Tropical de São Paulo. 2001;43:8791.

6. Sari A, Widaty S, Bramono K, Miranda E, Ganjardani M. Tinea kapitis di Poliklinik Kulit dan Kelamin RSUPN dr. Cipto Mangunkusumo Jakarta Periode Tahun 2005-2010. MDVI. 2012;39:113-7.

7. Tey HL, Tan AS, Chan YC. Meta-analysis of randomized, controlled trials comparing griseofulvin and terbinafine in the treatment of tinea capitis. J Am Acad Dermatol. 2011;64:663-70.

8. Bose SE, Kulkarni SG, Akhter I. The incidence of tinea capitis in a tertiary care rural hospital-a study. J Clin Diagn Res. 2011;5:307-11. 
9. Ginsburg CM, Gan VN, Petruska M. Randomized Controlled Trial of Intralesional corticosteroid and griseofulvin vs. griseofulvin alone for treatment of kerion. The Pediatr Infec Dis J. 1987;6:1084-7.

10. Meadows-Oliver M. Tinea capitis: diagnostic criteria and treatment options. Pediatric nursing. 2009;1;35:53.

11. Liu ZH, Zhang Y, Zhu J, Dai YQ, Shen H. Successful treatment of severe kerion Celsi in an immunocompromised girl with evacuation of pus, terbinafine and short course glucocorticosteroids. J Med Mycol. 2016;31:26:42-5.

12. Okafor UH. Pattern of Clinical Presentations in Immunocompromised Patient. INTECH Open Access Publisher; 2012. h.177-90.

13. Pandhi I, Pandhi SB, Pandhi S. Tinea Capitis in 31 Year Old Adult Male: A Rare Entity. J Clin Case Rep. 2015;13:2014.

14. Irimie $\mathrm{M}$, Oanta $\mathrm{A}$, Alexandrina Irimie $\mathrm{C}$, Loan Minea D. Prevalence and Antifungal Susceptibility Patterns of Dermatophytes Isolated from Patients with Neoplastic Diseases: A Case Control Study. Acta Dermatovenerologica Croatica. 2015;23:108.

15. Litt Jerome Z. Litt's Drug Eruptions and Reactions Manual. Edisi ke 19. Ohio : CRC press; 2013. h. 190.

16. Phan NQ, Blome C, Fritz F, Gerss J, Reich A, Ebata T, dkk. Assessment of pruritus intensity: prospective study on validity and reliability of the visual analogue scale, numerical rating scale and verbal rating scale in 471 patients with chronic pruritus. Acta dermatovenereologica. 2012 Sep 1;92:502-7.

17. Hjermstad MJ, Fayers PM, Haugen DF, Caraceni A, Hanks GW, Loge JH, dkk. Studies comparing Numerical Rating Scales, Verbal Rating Scales, and Visual Analogue Scales for assessment of pain intensity in adults: a systematic literature review. Journal of pain and symptom management. 2011:30;41:1073-93.

18. Rouzaud C, Hay R, Chosidow O, Dupin N, Puel A, Lortholary $\mathrm{O}$, dkk. Severe dermatophytosis and acquired or innate immunodeficiency: a review. Jof Fungi. 2015:31;2:4.

19. Lestarini D, Pratomo Untung S, Djuanda A. Peranan imunitas selular dalam dermatofitosis. MDVI.1995;22:126-30.

20. Lee MH, Yoo JY, Suh MK, Ha GY, Kim JR, Lee HJ. Kerion Celsi caused by Trichophyton verrucosum Probably transmitted from cattle. Korean J Med Mycol. 2012; 17: 230-35.

21. Maza luis M, Pezzlo Marie t, Baron Ellen J. Color Atlas of Diagnostic Microbiology. Edisi ke 5. California : MosbyYear Book inc; 1997.h.113-45.

22. Grover C, Arora P, Manchanda V. Comparative evaluation of griseofulvin, terbinafine and fluconazole in the treatment of tinea capitis. Int J Dermatol. 2012;51:455-8 